Jurnal Ilmu Keperawatan Komunitas Volume 1 No 18, Hal 18 -

24

November 2018

Persatuan Perawat Nasional Indonesia JawaTengah

\title{
ANALISA PENGARUH MEDITATION THERAPY \\ TERHADAP PENURUNAN KADAR GULA DARAH PADA DIABETESI
}

\author{
Tanty Febriana Audria'), Dwi Retnaningsih 2), Tamrin 3) \\ STIKES Widya Husada Semarang. \\ Email: dwiretnaningsih81@yahoo.co.id
}

\begin{abstract}
Background: The condition of the body when relaxation can affect blood glucose levels. The result of preliminary study in February 2018 in the working area of Puskesmas Mijen of Semarang City, obtained data that Diabetesi type 1 as many as 20 peoples. While people with Diabetesi type 2 as many as 89 peoples. Non pharmacology intervention is important to do in an effort to prevent the increase in blood glucose levels, one of them with Meditation Therapy. The aim of this study to determine the effect of Meditation Therapy to a Blood glucose Levels on Diabetesi In the work area of Puskesmas Mijen of Semarang City.

Methods: quasy experiment with pretest and post-test without control group design. This sampling techniques are using Cluster sampling technique with combination of Stratified Sampling. The amount of sample are 30 respondents with the estimated drop out $10 \%$ to 33 respondents. A guide to do Meditation Therapy using the Standard Operational Procedure (SOP) Meditation Therapy by Theo (2014).This data collection with observation sheet. The data were tested for normality test by using Saphiro Wilk test and analyzed by using Paired t test.
\end{abstract}

Results: After normality test of the data obtained the result that the data were normally distributed so statistical test carried out with Paired t test is known as p-value (sig.2-tailed) $=0,000$ which means smaller than $a=(0.05)$. So that, $\mathrm{HO}$ refused and Ha accepted.

Conclusions: There is an Effect of Meditation Therapy to a Blood glucose Levels of Diabetesi In Working Area of Puskesmas Mijen of Semarang City.

Keywords: Blood glucose Level, Meditation Therapy.

\section{PENDAHULUAN}

Penyakit Tidak Menular (PTM) menjadi masalah kesehatan masyarakat yang cukup besar di Indonesia saat ini. Hal ini ditandai dengan meningkatnya prevalensi penyakit tidak menular secara global di dunia dibandingkan dengan prevalensi penyakit menular. Selain itu, Secara nasional telah menduduki 10 besar penyakit penyebab kematian dan kasus terbanyak, yang diantaranya adalah Diabetes Melitus (DM) dan Penyakit Metabolik (PM) (Depkes, 2008).

Berdasarkan laporan statistik International Diabetes Federation (IDF) Indonesia menduduki peringkat keempat di dunia dengan jumlah penderita diabetes terbanyak setelah Amerika Serikat, China dan India. Saat ini ada sekitar 230 juta penderita diabetes dengan angka kejadian naik $3 \%$ atau
7 juta orang setiap tahun. American Diabetes Association (ADA) melaporkan bahwa setiap 21 detik ada satu orang yang terkena diabetes. Diperkirakan jumlah penderita diabetes di dunia akan semakin naik hingga mencapai 350 juta pada tahun 2025, lebih dari setengah Penderita Diabetes Melitus berada di Asia, terutama di India, Cina, Pakistan dan Indonesia (Tandra, 2014).

Data dari Badan Pusat Statistik (BPS) tahun 2010 menyatakan jumlah penderita diabetes di Indonesia tahun 2007 sebanyak 13.7 juta orang dan diperkirakan pada tahun 2030 penderita diabetes mecapai 20.1 juta penderita diabetes dengan tingkat prevalensi $14.7 \%$ untuk daerah urban dan $7.2 \%$ di daerah rural (Persi, 2011).

Berdasarkan Data Profil Kesehatan Provinsi Jawa Tengah tahun 2016, penderita diabetes melitus mencapai 209.319 kasus, 
terdiri atas pasien DM yang tidak tergantung insulin sebanyak 183.172 jiwa dan pasien yang tergantung insulin sebanyak 26.147 jiwa. Menurut Profil Kesehatan Kota Semarang tahun 2014 jumlah penderita Diabates melitus tipe II di Kota Semarang sebesar 1.66\%. Jumlah penderita di Kota Semarang mencapai 18.390 jiwa (Dinkes, 2016).

Tingginya angka prevalensi Penderita Diabetes Melitus disebabkan oleh beberapa faktor, diantaranya adalah faktor keturunan atau genetik, obesitas, perubahan gaya hidup, pola makan yang salah, obat-obatan yang mempengaruhi kadar glukosa darah, kurangnya aktivitas fisik, proses menua, kehamilan, dan perokok (Muflihatin, 2015).

Menurut Canadian Diabetes

Association (2014) menjelaskan bahwa penderita diabetes cenderung memiliki perasaan negatif seperti stres, marah dan rasa tidak berdaya. Respon tersebut timbul sebagai akibat buruknya prognosis penyakit diabetes. Pada penderita Diabetes Melitus dengan stres memiliki tingkat kesehatan yang jauh lebih buruk dibandingkan pada penderita yang hanya mengidap Diabetes Melitus ataupun stres saja (Waspadji, 2013).

Memburuknya prognosis penyakit DM menunjukkan pentingnya upaya pencegahan. Upaya yang dapat dilakukan yaitu melalui empat pilar penatalaksanaan DM seperti edukasi, latihan jasmani, terapi farmakologi dan perencanaan makan. Pendekatan edukasi dapat dilakukan dengan memberikan pendidikan kesehatan bagi para penderita Diabetes Melitus tentang pentingnya kepatuhan dalam menjalani segala rangkaian terapi farmakologi maupun non farmakologi.

\section{Pendekatan latihan}

jasmani dilakukan untuk mempercepat pemulihan glukosa otot sehingga dapat mencegah komplikasi akut dan mengurangi resiko

komplikasi jangka panjang. Pendekatan terapi farmakologi dilakukan dengan pemberian terapi insulin dan terapi obat hipoglikemik oral. Sedangkan pada terapi non farmakologi dapat dilakukan dengan pengaturan diet dan olah raga. Pengaturan diet akan merangsang timbulnya hormon endorphin yang dapat menghambat produksi hormon kortisol dan epineprin sehingga peningkatan kadar glukosa tidak terjadi. Selain itu terapi komplementer dapat digunakan bersamaan dengan terapi konvensional untuk mencegah peningkatan kadar gula darah. Sebuah studi yang dilakukan oleh Brook et all di tahun 2013 dengan judul "Beyond Medications and Diet: Alternative Approaches to Lowering Blood Pressuré" menggambarkan bukti yang mendukung Meditasi Transendental sebagai pengobatan hipertensi. Umumnya pengobatan yang sering digunakan bagi penderita diabetes di Eropa adalah Biologically based practice dan Mind Body Medicine (Wirawanda, 2014).

Berdasarkan konsep Mind Body Medicine, berbagai teknik didisain untuk meningkatkan pengaruh pikiran terhadap fungsi tubuh salah satunya dengan terapi relaksasi meditasi. Berdasarkan

Penelitian Dinardo(2009) dengan judul "Mind Body Medicine Therapies in Diabetes Management" menyatakan bahwa salah satu terapi pikiran adalah Yoga, qi-gong, Meditasi dan tehnik relaksasi lainnya. Meditasi dapat menurunkan kadar hormon stres dalam darah (Wirawanda, 2014).

Meditasi merupakan salah suatu teknik relaksasi yang didisain untuk meningkatkan sekresi hormon endorphine dengan cara mempengaruhi pikiran dalam mencapai kedamaian dan harmoni didalam diri atau mental individu dengan memusatkan perhatian terhadap satu objek tanpa memberikan kritikan (George, 2008). Meditasi memiliki efek relaksasi bagi tubuh, sehingga mampu merangsang kelenjar pituitary untuk mengeluarkan hormon endorphine dalam tubuh dan menekan hormon adrenal yang dapat memicu kenaikan 
glukosa darah (George, 2008). Efek Meditation Therapy juga berdampak pada kondisi psikologis seseorang. Penelitian yang dilakukan oleh Mohan Amit dkk pada tahun 2014 dengan judul "Effect of Meditation on Stress Induced Changes in Cognitive Functions" " menunjukkan bahwa Meditation Therapy efektif bagi orang-orang yang mengalami stres, kecemasan, depresi, fobia, insomnia dan sebagai terapi untuk menghilangkan ketergantungan pada obat dan alkohol.

Berdasarkan hasil studi pendahuluan yang dilakukan peneliti di Wilayah Kerja Puskesmas Mijen Semarang pada Maret 2018 didapatkan data bahwa 5 besar penyakit yang diderita oleh warga adalah darah tinggi (hipertensi), Diabetes Melitus, angina pectoris, stroke dan psikosis. Penderita Diabetes Melitus menempati urutan kedua dari lima besar penyakit terbanyak yang diderita oleh masyarakat sekitar Wilayah Kerja Puskesmas Mijen. Pada bulan Januari hingga Februari 2018 penderita Diabetes Melitus tipe 1 yang datang untuk periksa ke Puskesmas Mijen sebanyak 20 orang. Sedangkan penderita Diabetes Melitus tipe 2 yang datang untuk periksa ke Puskesmas Mijen sebanyak 89 orang dan jumlah tersebut semakin bertambah setiap bulan pada tahun 2018. Berdasarkan hasil wawancara peneliti dengan para Diabetesi di sekitar Wilayah Kerja Puskesmas Mijen, didapatkan data bahwa para Diabetesi mengatakan mengeluh sulit untuk tidur, kurang berolahraga, pola makan tidak terkontrol, dan tidak mengetahui cara mengontrol kadar gula darah secara mandiri. Sedangkan untuk sebagian Diabetesi mengeluhkan adanya stres jika kadar gula darah mereka mengalami peningkatan. Oleh karena itu, manajemen stres penting untuk dilakukan sebagai upaya mencegah peningkatan kadar gula darah salah satunya dengan Meditation Therapy sebagai terapi alternatif yang mudah untuk dilakukan.

Berdasarkan uraian tersebut, peneliti ingin melakukan penelitian dengan judul "Pengaruh Meditation Therapy terhadap Kadar Gula Darah pada Diabetesi di Wilayah Kerja Puskesmas Mijen Semarang”.

\section{METODE PENELITIAN}

Penelitian ini menggunakan jenis penelitian kuantitatif eksperimen. Menurut Sugiyono (2016) studi kuantitatif eksperimen merupakan metode penelitian yang digunakan untuk mencari apakah ada pengaruh dari perlakuan yang diberikan terhadap yang lain dalam kondisi yang terkendalikan dan data penelitian dinyatakan dalam angka serta dianalisis dengan tehnik statistik. Pengambilan data dilakukan dengan pendekatan studi quasy experiment yaitu mengungkapkan hubungan sebab akibat tanpa melibatkan kelompok kontrol dengan menggunakan jenis pretest and post- test without control group design (Nursalam, 2013). Penelitian ini dilakukan di Wilayah Kerja Puskesmas Mijen Semarang. Tempat penelitian tersebut dipilih karena memiliki Diabetesi tipe II yang banyak dan belum ada penelitian sejenis sebelumnya yang dilakukan di Wilayah Kerja Puskesmas Mijen.

Cara pengumpulan data pada penelitian ini menggunakan data primer dan data sekunder. Data primer pada penelitian ini adalah variabel kadar gula darah yang akan diukur dengan menggunakan alat Glukometer Gluco DR dan dokumentasikan menggunakan lembar observasi. Sedangkan data sekunder dalam penelitian ini didapat oleh peneliti dari data yang telah dikumpulkan oleh pihak Puskesmas Mijen seperti data dari bagian bidang keperawatan dan rekam medis.

Analisis data dilakukan dengan menggunakan analisia univariat dan bivariat, dimana analisa univariat untukmenjelaskan atau

mendiskripsikan karakteristik responden, dan menggambarkan kondisi setiap variabel penelitian, (Notoatmodjo, 2012). Analisis bivariat dalam penelitian ini 
dilakukan untuk membuktikan hipotesis penelitian yaitu mengetahui ada atau tidaknya pengaruh Meditation Therapy terhadap kadar kadar gula darah pada Diabetesi.

\section{HASIL DAN PEMBAHASAN Jenis Kelamin}

Hasil penelitian yang didapat dari 33 Diabetesi di wilayah kerja Puskesmas Mijen Kota Semarang menunjukkan bahwa sebagian besar jenis kelamin Diabetesi yaitu perempuan sebanyak 22 Diabetesi (66.7\%). Sedangkan jumlah diabetesi berjensi kelamin laki-laki sebanyak 11 orang (33.3\%). Banyaknya Diabetesi yang berjenis kelamin perempuan karena pada umumnya perempuan mengalami masalah berat badan (obesitas) disebabkan adanya peningkatan hormon estrogen yang menyebabkan peningkatan lemak pada jaringan subkutis, jaringan lemak tersebut akan menghambat kerja insulin (insulin resistence), terutama jika lemak tubuh terkumpul di pinggang (central obesity). Hal ini menyebabkan lemak memblokir kerja insulin karena menutup reseptor sehingga glukosa tidak dapat diangkut ke sel-sel dan menumpuk di dalam darah, akibatnya kadar gula darah meningkat (Srikandi, 2009).

\section{Pendidikan}

Hasil penelitian yang didapat dari 33 Diabetesi di wilayah kerja Puskesmas Mijen Kota Semarang menunjukkan bahwa sebagian besar Diabetesi memiliki tingkat pendidikan SMP yaitu sebesar 15 Diabetesi (45.5\%). Banyaknya Diabetesi yang memiliki tingkat pendidikan SMP mempengaruhi dalam pengetahuan Diabetesi dalam melakukan upaya pemantauan kadar gula darah melalui lima pilar penatalaksanaan Diabetes Melitus. Tingkat pendidikan seseorang mempengaruhi orang tersebut dalam membentuk perilakunya dalam perawatan diri (self care) penyakit diabetes melitus. Pengetahuan yang tinggi pada
Diabetesi mampu mengendalikan kadar gula darah menjadi normal (Wapadji, 2008).

Usia

Hasil penelitian yang didapat dari 33 Diabetesi di wilayah kerja

Puskesmas Mijen Kota Semarang menunjukkan bahwa sebagian besar umur Diabetesi yaitu sebanyak 16 Diabetesi (48.5\%) berumur 56 - 65 tahun. Banyaknya Diabetesi yang berumur 56 - 65 tahun dikarenakan adanya intoleransi terhadap glukosa yang akan meningkat sejalan dengan adanya pertambahan usia.

Pertambahan usia tersebut terjadi karena pada umumnya manusia mengalami perubahan fisiologis yang secara drastis menurun dengan cepat setelah usia 40 tahun (Waspadji, 2008).

\section{Pekerjaan}

Hasil penelitian yang didapat dari 33 Diabetesi di wilayah kerja Puskesmas Mijen Kota Semarang menunjukkan bahwa sebagian besar Diabetesi Tidak bekerja yaitu sebesar 14 Diabetesi (42.4\%). Banyaknya Diabetesi yang berprofesi tidak bekerja disebabkan oleh beberapa faktor. Salah satu faktor penyebabnya yaitu kurangnya aktivitas fisik. Aktifitas fisik dapat membakar kalori sehingga sel-sel lemak dapat berkurang dan insulin dapat menghantarkan glukosa darah masuk ke dalam sel sehingga kadar gula darah meningkat (Brunner \& Suddart (2011).

\section{Gambaran Kadar Gula Darah Sebelum Meditation Therapy}

\section{Tabel 1}

Gambaran Kadar Gula Darah sebelum

\begin{tabular}{llllll}
\multicolumn{5}{c}{ Meditation Therapy } \\
\hline $\begin{array}{l}\text { Variabel n } \\
\begin{array}{l}\text { Depende } \\
\mathrm{n}\end{array}\end{array}$ & & & & \\
\hline $\begin{array}{l}\text { Kadar Gula } \\
\begin{array}{l}\text { Darahpre } \\
\text { Meditation }\end{array}\end{array}$ & 33 & 126.337 .444 & $108-140$ & $23.69-128.97$ \\
\begin{tabular}{l} 
Therapy \\
\hline
\end{tabular} & & & & \\
\hline
\end{tabular}

Hasil penelitian yang didapat dari 33 Diabetesi di wilayah kerja Puskesmas Mijen 
Kota Semarang, menunjukkan nilai mean kadar gula darah pre Meditation Therapy sebesar $126.33 \mathrm{mg} / \mathrm{dl}$ atau masuk dalam batasan normal gula darah pada kelompok Diabetes. Hal tersebut erat hubungannya dengan sebagian besar usia responden yaitu berumur 56 - 65 tahun (48.5\%). Usia tersebut masuk dalam penggolongan usia menurut Depkes RI tahun 2009 yaitu golongan umur Lansia Akhir. Berdasarkan teori yang dikemukakan oleh Kumar \& Clarks pada tahun 2009 menyatakan bahwa meningkatnya kadar gula darah pada usia lanjut dapat juga terjadi karena penurunan sensitivitas reseptor insulin, penurunan regulasi hormon glukagon dan epineprin yang berperan dalam kadar gula darah.

\section{Gambaran Kadar Gula Darah Setelah Meditation Therapy}

\section{Tabel 2}

\section{Gambaran Kadar Gula Darah setelah}

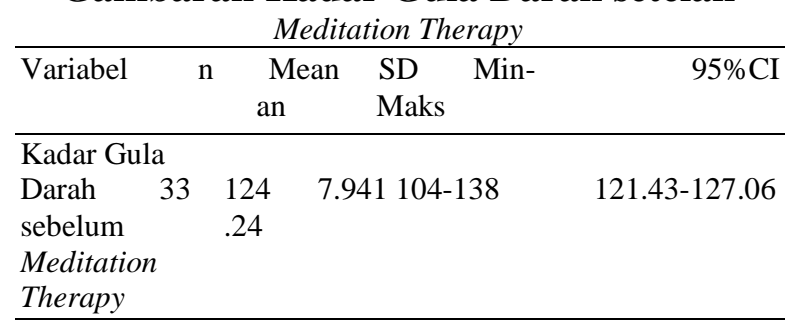

Hasil penelitian yang didapat dari 33 Diabetesi di wilayah kerja Puskesmas Mijen Kota Semarang, menunjukkan Nilai mean kadar gula darah post Meditation Therapy sebesar $124.24 \mathrm{mg} / \mathrm{dl}$ masuk dalam kelompok golongan Diabetes disebababkan oleh kurangnya aktivitas para responden. Hal tersebut dibuktikan berdasarkan hasil penelitian bahwa sebagian besar responden tidak bekerja (48.5\%). Menurut Brunner \& Suddart (2011) menyatakan bahwa kurangnya aktivitas fisik akan menurunkan daya penyerapan atau metabolisme gula dan lemak di dalam sel otot atau sel jaringan, sehingga dapat meningkatkan konsentrasi gula dan lemak di dalam darah. Selain itu menurut Smeltzer and Bare (2009) menyatakan bahwa ketika penderita diabetes melitus melakukan aktivitas fisik maka akan menurunkan resistensi insulin dan meningkatkan sensitivitas insulin. Oleh sebab itu akan memicu penurunan kebutuhan akan insulin. Faktor lain yang juga menyebabkan nilai mean kadar gula darah post Meditation Therapy masuk dalam kelompok golongan Diabetes adalah kebiasaan merokok pada Diabetesi berjenis kelamin laki- laki. Berdasarkan hasil wawancara peneliti dengan responden laki-laki didapatkan data bahwa sebagian besar responden merupakan perokok aktif. Asap rokok yang mengandung nikotin dapat menyebabkan insulin tidak bekerja dengan baik, memperburuk metabolisme gula di dalam darah, dan menyebabkan terjadinya peradangan pankreas. Mekanisme nikotin dapat menyebabkan resistensi reseptor insulin yaitu nikotin akan menempel pada nicotinic acetylcolinesterase (NAchR) dan merangsang kerja dari mTOR. mTOR bertanggung jawab terhadap pertumbuhan sel, dimana jika aktivitas mTOR berlebihan akan terjadi pertumbuhan sel yang abnormal dan poliferasi dari reseptor IRS-1 Ser 636 sehingga insulin tidak mengenali reseptornya lagi. Peningkatan reseptor IRS-1 Ser 636 yang abnormal akan menurunkan insulin glucose uptake sehingga terjadi resistensi reseptor insulin maka kadar gula darah meningkat.

\section{Pengaruh Meditation Therapy terhadap Kadar Gula Darah}

Tabel 3

Pengaruh Meditation Therapy terhadap Kadar Gula Darah

\begin{tabular}{|c|c|c|c|c|c|c|}
\hline Kadar & M & $\mathrm{N}$ & Std & Std & $\mathrm{t}$ & $p$ \\
\hline Gula & ea & & Deviati & Error & & valu \\
\hline Darah & $\mathrm{n}$ & & on & Mea & & $e$ \\
\hline $\begin{array}{l}\text { Sebelum } \\
\text { diberi }\end{array}$ & & & & $\mathrm{n}$ & & $\begin{array}{l}\text { (sig. } \\
2-t a\end{array}$ \\
\hline Meditati & & & & & & iled) \\
\hline $\begin{array}{c}\text { on } \\
\text { Therapy }\end{array}$ & & & & & & \\
\hline Pre Med & 12 & 3 & 7.444 & 1.29 & 7.65 & 0.00 \\
\hline & 6.3 & 3 & 7.941 & 6 & 8 & 0 \\
\hline Post & 3 & & & 1.38 & & \\
\hline Med & & 3 & & 2 & & \\
\hline
\end{tabular}




\begin{tabular}{cc}
12 & 3 \\
4.2 & \\
4 & \\
\hline
\end{tabular}

Hasil penelitian yang didapat dari 33 Diabetesi di wilayah kerja Puskesmas Mijen Kota Semarang, menggambarkan rata-rata kadar gula darah responden sebelum Meditation Therapy adalah $126.33 \mathrm{mg} / \mathrm{dl}$ dan rata-rata kadar gula darah responden setelah Meditation Therapy adalah $124.24 \mathrm{mg} / \mathrm{dl}$. Hasil uji Dependent Sample t Test (Paired $t$ test), diketahui bahwa nilai p-value (sig.2tailed $)=0.000$ yang berarti lebih kecil dari a $=0.05$ sehingga $\mathrm{H} 0$ ditolak dan Ha diterima, maka disimpulkan bahwa ada pengaruh yang significant Meditation Therapy terhadap kadar gula darah pada Diabetesi di wilayah kerja Puskesmas Mijen Kota Semarang. Pemberian Meditation Therapy di wilayah kerja Puskesmas Mijen dilakukan selama tujuh kali perlakuan selama tujuh hari berturut- turut dengan durasi 15 menit dan diberikan pre test berupa pengukuran kadar gula darah pada hari pertama sebelum dilakukan Meditation Therapy dan responden diberikan post test berupa pengukuran gula darah dengan menggunakan glukometer pada hari ketujuh setelah dilakukan Meditation Therapy. Responden melakukan Meditation Therapy setiap pukul 06.30 WIB yang dipimpin oleh peneliti dan dilakukan di dalam dengan kondisi yang sunyi jauh dari keramaian. Berdasarkan hasil penelitian disimpulkan bahwa ada pengaruh Meditation Therapy terhadap Kadar Gula Darah pada Diabetesi di Wilayah Kerja Puskesmas Mijen Kota Semarang dengan nilai p-value $($ sig.2-tailed $)=0,000$ yang berarti lebih kecil dari $\mathrm{a}=0.05$. Pengaruh yang terjadi yaitu adanya penurunan rata-rata kadar gula darah setelah dilakukan Meditation Therapy.

\section{KESIMPULAN}

1. Kadar gula darah pre Meditation Therapy terendah adalah $108 \mathrm{mg} / \mathrm{dl}$ dan kadar gula darah pre Meditation Therapy tertinggi adalah $140 \mathrm{mg} / \mathrm{dl}$.
2. Kadar gula darah post Meditation Therapy terendah adalah $104 \mathrm{mg} / \mathrm{dl}$ dan kadar gula darah post Meditation Therapy tertinggi adalah $138 \mathrm{mg} / \mathrm{dl}$.

3. Rata-rata kadar gula darah Diabetesi sebelum Meditation Therapy adalah $126.33 \mathrm{mg} / \mathrm{dl}$ dan rata-rata kadar gula darah Diabetesi setelah Meditation Therapy adalah $124.24 \mathrm{mg} / \mathrm{dl}$.

4. Hasil uji Dependen Sample t Test (Paired $t$ test), diketahui bahwa nilai p-value (sig.2-tailed $)=0,000$ yang berarti lebih kecil dari $\mathrm{a}=0.05$ sehingga $\mathrm{H} 0$ ditolak dan Ha diterima.

5. Ada Pengaruh Meditation Therapy terhadap kadar gula darah pada Diabetesi di wilayah kerja Puskesmas Mijen Kota Semarang.

\section{REFERENSI}

Brunner \& Suddart. (2011). Keperawatan Medikal Bedah. Edisi 8. Jakarta: EGC.

Canadian Diabetes Association (CDA). (2014). Canadian Diabetes 2014 Clinical Practice Guidelines for the Prevention and Management of Diabetes in Canada. Canadian Journal of Diabetes Volume 32. No 1. Diakses pada tanggal 20 Januari 2018. http://guidelines.diabetes.ca/ful lguidelines\&ved=2ahUKEwiso LKMyPDaAhVBK48KHZRC DI8QFjAAegQIBhAB\&usg=A OvVaw2Gn 8nduL19xgEs6eS- B69

Depkes RI. (2008). Pedoman Pengendalian Diabetes Melitus dan Penyakit Metabolik. Direktorat Pengendalian

Penyakit Tidak Menular. Jakarta.

Dinas Kesehatan Provinsi Jawa Tengah. (2016). Data Dinas Kesehatan Provinsi Jawa Tengah. Diakses pada tanggal 20 Januari 2018. http://www.depkes.go.id/resour 
ces/download/profil/PROFIL KES

PROVINSI 2016/13 Jat eng

2016.pdf\&ved $=2$ ahUKEw juj

qawyPDaAhUGp48KHR7v

DsoQFjAAegQIAhAB\&usg=A

OvVaw33hqC93CAmpProCx2 FuEsh

George. (2008). Concentration and Meditation. New York: TEACH services.

International Diabetes Federation. (2013). IDF Diabetes Atlas Sixth Edition (Online).

Kumar, P., \& Clark, M. L. (2009). Kumar \& Clark's Clinical Medicine 7 th Edition. Spain: Elsevier.

Muflihatin, K.S. (2015). Hubungan Tingkat Stress dengan Kadar

Glukosa Darah Pasien Diabetes Melitus Tipe 2 di RSUD Abdul Wahab Syahranie Samarinda. Jurnal STIKES Muhammadiyah Samarinda. Diakses tanggal 27 Februari 2018.

https://media.neliti.com/media/

publications/105312-ID-

hubungan-tingkat-stres-

dengan-kadar

gula.pdf\&ved $=2 \mathrm{ahUKEwiYwJ}$

KbxvDaAhUEL48KHR8RCx0

QFiAAegQICBAB\&usg=AOv

Vaw04WyiXWak3uBAiwF3c

Oma5

Notoadmodjo, Sukidjo. (2012). Metodologi

$$
\text { Penelitian }
$$

Kesehatan. Jakarta: Rineka Cipta

Nursalam. (2013). Metodologi Penelitian Ilmu Keperawatan: Pendekatan Praktis. Edisi 3. Jakarta: Salemba Medika.

Perkumpulan Endokrinologi Indonesia (Perkeni). (2011). Konsesus Pengelolaan dan Pencegahan Diabetes Melitus Tipe 2 di Indonesia. Jakarta: Author.

Profil Kesehatan Provinsi Jawa Tengah. (2016). Data Penyakit Tidak Menular (PTM) Provinsi Jawa Tengah. Diakses pada tanggal 18 Januari 2018.

http://www.depkes.go.id/resour

ces/download/profil/PROFIL KES

PROVINSI 2016/13 Jat eng

2016.pdf\&ved=0ahUKEw i08NWOx

DaAhWILI8KHep-

CGUQFgj3ATAb\&usg=AOvV

aw33hqC93CAmpProCx2FuEs h

Riyanto, Theo. (2014). Meditasi

Penyembuhan: Tuntunan

Menjadi Manusia Integral dan

Seimbang. Jakarta: PT

Kanisius.

Smeltzer,Suzzanne C., \& Bare,

Brenda G. (2009). Textbook of Medical

Surgical Nursing. (10th.ed).Vol.2.

Philadelphia: Lippincott William \& Wilkins.

Sugiyono. (2016). Metode Penelitian Kuantitatif, Kualitatif Dan $R \& D$. Bandung : PT Alfabet.

Tandra, Hans. (2014). Segala Sesuatu yang Harus Anda Ketahui Tentang Diabetes. Jakarta: PT. Gramedia Pustaka Utama

Waluyo, Srikandi. 2009. Questions \& Answers Diabetes. Jakarta: PT Elex Media Komputindo.

Waspadji. 2008. Diabetes Melitus: Menkanisme Dasar dan Pengelolaannya yang Rasional dalam Penatalaksanaan Diabetes Melitus Terpadu. Jakarta: Penerbit FKUI

Waspadji, dkk. (2013). Ende Diabetes Study: diabetes and its characteristics in rural area of East Nusa Tenggara. Medikal Journal of Indonesia, Vol 22, No 1 diakses pada tanggal 5 Januari2018 dari

http://mii.ui.ac.id/iounal/index, php/mii/rt/printerFriendlv/517/ 0 .

Wirawanda, Y. (2014). Kedahsyatan Terapi Yoga. Jakarta Timur: Padi. 